\title{
Towards evenly distributed grazing patterns: Including social context in sheep management strategies
}

Agustina di Virgilio, Juan Manuel Morales

Background: A large proportion of natural grasslands around the world is exposed to overgrazing resulting in land degradation and biodiversity loss. Although there is an increasing effort in the promotion of sustainable livestock management, rangeland degradation still occurs because animals' foraging behaviour is highly selective at different spatial scales. The assessment of the ecological mechanisms modulating the spatial distribution of grazing and how to control it has critical implications for long term conservation of resources and the sustainability of livestock production. Considering the relevance of social interactions on animals' space use patterns, our aim was to explore the potential effects of including animals' social context into management strategies using domestic sheep grazing in rangelands as case study.

Methods: We used GPS data from 19 Merino sheep (approximately 10\% of the flock) grazing on three different paddocks (with sizes from 80 to $1000 \mathrm{Ha}$ ) during a year, to estimate resource selection functions of sheep grazing in flocks of different levels of heterogeneity. We assessed the effects of sheep class (i.e., ewes, wethers, and hoggets), age, body condition and time since release on habitat selection patterns.

Results: We found that social rank was reflected on sheep habitat use, where dominant individuals (i.e., reproductive females) used more intensively the most preferred areas and low-ranked (i.e., yearlings) used less preferred areas. Our results showed that when sheep grazed on more heterogeneous flocks, grazing patterns were more evenly distributed at all the paddocks considered in this study. On the other hand, when high-ranked individuals were removed from the flock, low-ranked sheep shifted their selection patterns by increasing the use of the most preferred areas and strongly avoided to use less preferred sites (i.e., a highly selective grazing behaviour).

Discussion: Although homogenization and segregation of flocks by classes are common practices to increase flock productivity, we are proposing an alternative that employs behavioural interactions in heterogeneous flocks to generate more evenly distributed grazing patterns. This practice can be combined with other practices such as rotational grazing and guardian dogs (to decrease mortality levels that may be generated by sheep grazing on more risky habitats). This does not imply any modifications of livestock stocking rates and densities or any additional investments for labour and materials. Considering livestock behaviour is critical for the design of sustainable management practices that balance landscape conservation and livestock productivity. 
3 di Virgilio, Agustina ${ }^{1}$ and Morales, Juan Manuel ${ }^{1}$.

4 'Grupo de Ecología Cuantitativa, INIBIOMA, CONICET-UnComa, Bariloche, Río Negro, Argentina.

5 Corresponding author: di Virgilio Agustina ${ }^{1}$

6 Quintral 1250, Bariloche, Argentina (8400)

7 e-mail address: adivirgilio@comahue-conicet.gob.ar

8 Short title: Socially-modulated grazing patterns

\section{Summary:}

10 Background: A large proportion of natural grasslands around the world is exposed to overgrazing

11 resulting in land degradation and biodiversity loss. Although there is an increasing effort in the promotion

12 of sustainable livestock management, rangeland degradation still occurs because animals' foraging

13 behaviour is highly selective at different spatial scales. The assessment of the ecological mechanisms

14 modulating the spatial distribution of grazing and how to control it has critical implications for long term conservation of resources and the sustainability of livestock production. Considering the relevance of social interactions on animals' space use patterns, our aim was to explore the potential effects of including animals' social context into management strategies using domestic sheep grazing in rangelands as case study.

Methods: We used GPS data from 19 Merino sheep (approximately 10\% of the flock) grazing on three different paddocks (with sizes from 80 to $1000 \mathrm{Ha}$ ) during a year, to estimate resource selection functions of sheep grazing in flocks of different levels of heterogeneity. We assessed the effects of sheep class (i.e., ewes, wethers, and hoggets), age, body condition and time since release on habitat selection patterns.

Results: We found that social rank was reflected on sheep habitat use, where dominant individuals (i.e., reproductive females) used more intensively the most preferred areas and low-ranked (i.e., yearlings) used 
25 less preferred areas. Our results showed that when sheep grazed on more heterogeneous flocks, grazing

26 patterns were more evenly distributed at all the paddocks considered in this study. On the other hand,

27 when high-ranked individuals were removed from the flock, low-ranked sheep shifted their selection

28 patterns by increasing the use of the most preferred areas and strongly avoided to use less preferred sites

29 (i.e., a highly selective grazing behaviour).

30 Discussion: Although homogenization and segregation of flocks by classes are common practices to increase flock productivity, we are proposing an alternative that employs behavioural interactions in heterogeneous flocks to generate more evenly distributed grazing patterns. This practice can be combined with other practices such as rotational grazing and guardian dogs (to decrease mortality levels that may be generated by sheep grazing on more risky habitats).This does not imply any modifications of livestock stocking rates and densities or any additional investments for labour and materials. Considering livestock behaviour is critical for the design of sustainable management practices that balance landscape conservation and livestock productivity.

\section{Introduction}

A large fraction of natural grasslands around the world is exposed to overgrazing and high stocking rates, leading to land degradation and biodiversity loss of an environment that besides holding key natural resources sustains socio-economically a vast proportion of human population (MA 2006; FAO 2009; Sayre et al. 2013). Even though there is an increasing effort in the promotion of sustainable range management (Morghan, Sheley \& Svejcar 2006; Briske et al. 2008; Boyd \& Svejcar 2009), rangeland degradation still occurs because grazing behaviour is highly selective at different spatial scales (Senft et al. 1987; Bailey et al. 1996). These heterogeneous patterns of space use often produce overgrazing at the most preferred areas while other areas remain under-grazed (Bailey, Dumont \& WallisDeVries 1998; Pringle \& Landsberg 2004). Although herbivores' movement decisions are related to the distribution of resources (e.g. Fortin, Fryxell \& Pilote 2002; Fryxell, Wilmshurst \& Sinclair 2004), for animals living in

49 groups, social context can also be an important factor influencing their movement and patterns of space 
50 use (Scott, Provenza \& Banner 1995; Scott, Banner \& Provenza 1996; Couzin et al. 2005; Haydon et al.

51 2008). As a consequence, the movement patterns of gregarious herbivores can result in socially-generated

52 disturbances that are somehow independent of resource distributions (Bailey et al. 2001; Seabloom \&

53 Reichman 2001; Bailey 2004).

54 The social environment of group-living herbivores has several benefits on individual fitness that are 55 related to knowledge transmission from conspecifics' experiences (Scott, Provenza \& Banner 1995; e.g. 56 Scott, Banner \& Provenza 1996) and minimization of predation risk (Pinchak et al. 1991; Plumb \& Dodd 57 1993; Etzenhouser et al. 1998; Fortin et al. 2003; Fortin et al. 2005; Frair et al. 2005; Rubio et al. 2008; 58 Fortin et al. 2009). Nevertheless, when resources are scarce and heterogeneously distributed across the 59 landscape, animals have to balance the benefits of group living with the competition for resources 60 (Childress \& Lung 2003; Veiberg et al. 2004; Fortin et al. 2009). This trade-off may contribute to the 61 development of hierarchical structures, in which animals are part of a social rank that could determine 62 their grazing and movement patterns (Thouless 1990; Veiberg et al. 2004). Regardless of which factors 63 determine an animal's position in a social rank, once the hierarchy is established, higher-rank individuals 64 have priority access to preferred areas while lower-rank individuals use less preferred areas in the 65 landscape which otherwise would be underused (Petocz 1973; Bøe, Berg \& Andersen 2006).

66 Our general aim was to explore the potential effects ofincluding the animals' social context into 67 management strategies using domestic sheep (Ovis aries, Linnaeus 1758) grazing in Patagonian 68 rangelands as case study. Particularly, we wanted to explore which factors influenced the development of a 69 social rank when sheep graze in heterogeneous flocks and if this social structure favours the development 70 of more evenly distributed grazing patterns. Considering that animals could show different movement 71 behaviours according to their age (e.g., Favre, Martin \& Festa-Bianchet 2008), sex (e.g., Michelena et al. 72 2005), nutritional condition and their energy requirements (e.g., Vervaecke, Roden \& De Vries 2005) we 73 assessed their influence on sheep selection patterns.

\section{Material \& Methods}




\section{Study area}

76 Empirical data on sheep movement, body condition, and landscape traits were collected at Fortín

77 Chacabuco Ranch (Supplemental Information S1). This farm is located in Los Lagos department (NW

78 corner at $40^{\circ} 57^{\prime} 04.58^{\prime \prime} \mathrm{S}, 71^{\circ} 08^{\prime} 44.14^{\prime \prime} \mathrm{W}$; SW corner at $40^{\circ} 59^{\prime} 45.27^{\prime \prime} \mathrm{S}, 71^{\circ} 12^{\prime} 10.21^{\prime \prime}$ W;NE corner

79 at $40^{\circ} 59^{\prime} 17.54^{\prime \prime} \mathrm{S}, 71^{\circ} 05^{\prime} 52.75^{\prime \prime} \mathrm{W}$; SE corner at $41^{\circ} 03^{\prime} 09.17^{\prime \prime} \mathrm{S}, 71^{\circ} 08^{\prime} 16.45^{\prime \prime} \mathrm{W}$ ) and belongs to

80 the Pre-mountain range ecological area of Argentinean Patagonia(Cabrera 1976). The landscape is

81 characterized by mountain chains and hills, crossed by several rivers and water streams. The weather is

82 cold, with mean annual temperatures of $10^{\circ} \mathrm{C}$ and annual precipitations that range from 300 to $700 \mathrm{~mm}$,

83 concentrated during the cold season (i.e. May-August). Vegetation corresponds to the Sub-Andean district

84 (León et al. 1998), composed by grasslands (dominated by Stipas peciosa var major in lower lands and by

85 Festuca pallescens in upper lands), and wetlands of different extensions. Smaller wetlands are frequently

86 associated to native and riparian forests. This ranch is characterized by high heterogeneity in sheep grazing

87 patterns, with some areas intensively used and with degradation signs, and others under-used with high

88 levels of litter accumulation from un-grazed senescent plants that decreases their productivity

89 (Paramidani, Doffigny \& Codesal 2014).

90 Data collection and spatial data processing

91 Landscape data:

92 In order to characterize the landscape where sheep grazed, we mapped the vegetation units of each

93 paddock were livestock was kept during the sampling period. First, we identified and defined polygons of

94 landscape units that we were able to classify using Google Earth imagery (Digital Globe Quickbird.

95 Resolution: 15 m per pixel. 10-16-2013. Accessed: September 2014.Supplemental Information S1-fig.1);

96 then we corroborate and defined each polygon's limits by matching them with an unsupervised

97 classification from a Landsat TM (2011) satellite image using ArcGIS (ESRI 2011. ArcGIS Desktop10.1.

98 Redlands, Environmental Systems Research Institute). This classification was then validated through

99 vegetation sampling that consisted in placing transects inside each polygon, in which we located a $1 \mathrm{~m}^{2}$ 
100 plot every $100 \mathrm{~m}$. These points were selected previous to fieldwork on a Google Earth file containing the 101 polygons of vegetation units. The number of transects depended on the size of each polygon (i.e., in wider 102 polygons we placed two or more transects), and the length depended on the polygon's length. In each plot we registered every plant species present, their percentage of cover, and the percentage of cover of litter and bare ground. The species were recognized in the field, and we took samples only from those specimens that could not be identified in the field (permit number 1339).By using a vegetation guides for this region (e.g., Bonvissuto \& Somlo 1995) we were able to identify eight main landscape units: central wetland, peripheral wetland, grassland, shrubland-grassland, native forest (dominated by Maytenus boaria, Austrocedrus chilensis, and Nothofagus spp.), riparian forest (associated with streams and water courses), high-lands (with rocky peaks which provide shadow during summer) and low production areas (which are eroded areas, with high proportions of bare ground and low levels of forage). Additionally, during those vegetation surveys we registered GPS locations of sheep carcasses and faeces from pumas and foxes to identify which vegetation units present higher predation risk (see Supplemental Information S1, Table S1.4).

For this study, we considered three paddocks, called Repunte-Bajo (RB), Frison-Guanaco (FG) and Side (S), which have sizes of 79, 944 and $146 \mathrm{Ha}$, respectively. This range of sizes among paddocks is representative for the paddocks used commonly in Patagonian rangelands for sheep production (see examples in Irisarri et al. 2012; Ormaechea \& Peri 2015). Information about the surface of each landscape unit, the amount of forage species, bare ground and predation risk levels of each paddock can be found in Supplemental Information S1. Central and peripheral wetlands were considered the most preferred landscape resources because they contain higher forage production. Native forests have relatively high quantities of forage and riparian forests are areas associated with semi-permanent water courses, but are closed areas with lower probabilities of predator detection (Risenhoover \& Bailey 1985; Kie 1999) and high numbers of carcasses and predators' faeces (Supplemental Information S1, table S1.4). Grasslands and shrubland-grasslands are areas with moderate to low quantities of forage and predation risk signs. 
126 sheep use as shaded areas during summer and as wind refuges during winter (di Virgilio personal

127 observation). Finally, low production areas are sites of moderate-low elevation with the lowest quantities

128 of forage observed in the landscape.

129 Sheep data:

130 We selected 19 sheep from a flock of approximately 200 individuals, composed of $38 \%$ of ewes (i.e., 131 reproductive females), $28 \%$ of hoggets (i.e., female and male yearlings), $31 \%$ of wethers (i.e., castrated 132 males), and 3\% of rams (reproductive males). In order to have a representative sample of these sheep 133 classes (rams were kept apart from the flock during the sampling period), we selected 6 ewes, 7 hoggets, 134 and 6 wethers. Sheep were equipped with GPS devices attached to collars (CatLog-B, Perthold 135 Engineering, www.perthold.de; USA). Collared animals were marked for identification with a unique ID 136 number and colour according to sheep class. The sampled animals were always the same individuals for 137 all the sampling periods, and sheep wore the collars almost continuously for the whole duration of the experiment. The devices were programmed to acquire locations every 5 minutes, from September 2014 to September 2015.We used a Body Condition Score (BCS, Jefferies 1961; Giraudo 2010), as an indirect method to assess sheep fat reserves and estimated sheep' age by their number of permanent teeth. Initial BCS of sheep and age were measured at the beginning of the sampling period. BCS ranged from 2.25 to 4 and ages ranged from 6 months to more than 4 years old (i.e., from 0 permanent teeth to 8 permanent teeth). We also measured BSC of all collared individuals every time the flock was translocated into the paddocks. We considered heterogeneous flocks (hereafter 3-class mixed flocks) as those composed of all sheep classes (i.e., ewes, hoggets and wethers) and less heterogeneous flocks (hereafter 2-class mixed flocks) as flocks with two sheep classes (e.g., ewes and hoggets, or wethers and hoggets). Because our research was conducted on non-regulated animals we did not required any ethical approval.

To assess if patterns of space use by sheep are more evenly distributed when animals graze in 3-class mixed flocks and to detect which individuals have priority access to most preferred areas, we selected 
152 Golluscio, Deregibus \& Paruelo 1998) during lambing (i.e., when ewes give birth to lambs, approximately 153 between October-November) and during weaning (i.e, when wethers and lambs were separated, 154 approximately between January-February). To evaluate if sheep increase their selectivity under less 155 heterogeneous mixed flocks, and if subordinates change their landscape use patterns when high-ranked 156 individuals are removed from the flock, we used the following data sets: (i) Data from wethers and 157 hoggets grazing when ewes were extracted from the flock during the lambing period ( $\mathrm{RB}_{2 \mathrm{C}-\mathrm{mixed}}$, see 158 Table 1); and (ii) data from ewes and hoggets grazing when wethers were extracted from the flock during 159 weaning $\left(\mathrm{S}_{2 \mathrm{C}-\text { mixed }}\right.$, see Table 1$)$. Both databases included GPS locations of individuals that experienced 160 both flock types in the same paddock.

161 In all cases, we used only diurnal locations when sheep are mainly grazing (Dudzinsky \& Arnold 1978).

162 As a result, the total number of GPS locations to be included in the data analysis for Repunte-Bajo, 163 Frison-Guanaco and Side paddocks were: 147 905, 208275 and 28976 respectively. The number of 164 random points generated for statistical analyses (see below) was double of GPS locations for the three 165 paddock, which represented a good balance between the quality of the availability estimation and 166 computational demands (Northrup et al. 2013). The spatial data analysis was performed with R software 167 (R Core Team 2015). All information about spatial data analysis can be found in Supplemental 168 Information S2.

\section{Data analysis}

To assess sheep resource selection patterns at landscape scale, we focused our analyses on availability vs. use of resources (e.g. Johnson et al. 2006; Beyer et al. 2010), where different resources are represented by the different vegetation units present in the landscape. This requires measuring the use of resources relative to their availability: a positive ratio indicates that animals are selecting a particular resource, a negative ratio suggests avoidance, and the magnitude of the ratio indicates the degree of the selection/avoidance. In particular, we estimated Resource Selection Functions (RSF, Manly et al. 2002), by fitting logistic regressions, assuming a Bernoulli distribution for the response variable and a logit link 
177 function. We used a Bayesian approach to fit a hierarchical logistic regression for each paddock allowing

178 for individual differences in sheep responses and considering the lack of independence between the 179 consecutive GPS locations (see Supplemental Information S3). The dependent variable for the RSF was 180 the GPS locations (ones) combined with simulated random locations (zeroes) across the total surface of 181 each paddock that approximate the availability of resources. The resources considered were landscape 182 vegetation units: low production areas, high-lands, central wetlands, peripheral wetlands, grasslands, 183 shrubland-grasslands, native forestsand riparian forests.

184 To assess the effect of social structure on the use of landscape resources, we fitted a hierarchical logistic model using time since release (as the number of days since the release in the paddock), sheep class, age and body condition score as co-variables. Continuous variables were centred and standardized. See model structure in Supplemental Information S3. To evaluate if sub-dominant individuals shift their space use patterns when dominant sheep are removed from the flock, we fitted a hierarchical logistic model using as independent variable time since release, sheep type and flock type (i.e., 3-class vs. 2-class). See model structure in Supplemental Information S3. All analyses were performed using R (R Core Team 2015) and WinBUGS (Spiegelhalter et al. 1996). Details on parameters' and hyper-parameters' priors and the number of iterations for each Monte Carlo Markov Chain (MCMC) can be found in Supplemental Information S3. We checked for convergence and autocorrelation of the posterior distributions and estimated the 95\% Highest Posterior Density (HPD) intervals for all parameters. To assess if resource selection patterns differed among sheep classes, we calculated the proportion of posterior distribution overlapping of the parameters for each landscape resource between (i) ewes-hoggets, (ii) ewes- wethers, and (iii) hoggets-wethers in each paddock. To evaluate the differences of resource selection under both types of flocks, we calculated the proportion of posterior distribution overlapping between the estimates of

199 3-class and 2-class mixed flocks for each resource in each paddock.

\section{Results}


201 We found that when sheep were maintained in more heterogeneous flocks they selected almost all

202 vegetation units with similar intensities and strongly avoided low production areas or riparian forests (fig.

203 1). Furthermore, we found that for the areas with higher forage production (i.e., central and peripheral

204 wetlands) and for less preferred areas (i.e., low production sites and riparian forests), the patterns of

205 resource selection differed among sheep classes. This resulted in ewes selecting more intensively the most

206 productive areas and avoiding with more strength the less preferred areas; while hoggets and wethers

207 selected landscape resources similarly (fig. 1, Supplemental Information S4: Table S4.1, Supplemental

208 Information S5). We did not detect effects of time since release, age or BCS on sheep selection patterns

209 (RSF coefficients were close to zero and HPD-intervals included zero. See Supplemental Information S4,

210 Table S4.2). These patterns of more evenly distributed use and differences among sheep classes were

211 observed at the three paddocks evaluated (figs. 1 and 4, Supplemental Information S5).

212 When sheep were kept in less heterogeneous flocks, we noticed that the outcome of the resource selection 213 patterns depended on which sheep class was removed (figs. 2 and 3). When wethers were removed, the 214 selection patterns resulted similar to those in 3-class mixed flocks (figs. 3a and 3b), and neither ewes nor 215 hoggets showed major changes in their landscape use. Nevertheless, when ewes were removed from the 216 flock, it resulted in a more unevenly distributed space use, with higher selection of most preferred areas 217 (i.e., central and peripheral wetlands) and higher avoidance of the rest of the landscape units (especially 218 for low production areas and both types of forests). Moreover, hoggets were the sheep class that showed a 219 marked switch in their resource selection patterns in comparison to wethers (figs. 2a, 2b and 4; 220 Supplemental Information S5).

\section{Discussion}

222 This work provides information about a possible mechanism underlying the generation of more evenly distributed grazing patterns, which is related to ecological and behavioural aspects of livestock and can be employed as a tool for the development of sustainable livestock management strategies. Our outcomes 
226 distribution of grazing, independently of the paddock in which sheep grazed. On the other hand, we 227 observed that this evenly distributed grazing patterns could be easily overridden by common management 228 practices that tend to maintain more uniform groups to increase flock productivity (Arnold \& Pahl 1974; 229 Stenseth 1983; Lynch et al. 1989; Borrelli et al. 1997; Borelli \& Oliva 2001), such as flock segregation 230 according to nutritional requirements or culling, among others. Finally, we noticed a shift from an evenly 231 distributed grazing pattern toward a more selective one only when dominant individuals were removed 232 from the flock.

233 Although there is evidence that food preferences, weather, forage distribution and predators influence 234 herbivores grazing patterns (Scott, Provenza \& Banner 1995; Prache, Gordon \& Rook 1998), we propose that social interactions are also important factors influencing landscape use and ultimately population dynamics (Morales et al. 2010). This is particularly relevant for gregarious animals like livestock and we believe that it should be considered into management strategies in addition to the rest of the factors. Commonly, social interactions among group members result in dominance structures or social ranks (Lynch, Hinch \& Adams 1992; Erhard et al. 2004) that are reflected in their spatial distribution when grazing (see Lynch, Hinch \& Adams 1992; Sibbald, Shellard \& Smart 2000). We observed that ewes selected with more intensity the most preferred areas in comparison to hoggets and wethers that showed higher selectivity towards less preferred areas when sheep were maintained in more heterogeneous flocks.

243 This pattern could be indicating the development of a well established social rank, in which ewes are 244 dominant and have preferential access to resources, as was previously observed in other studies with sheep 245 (Lynch, Wood-Gush \& Davies 1985; Eccles \& Shackleton 1986; Festa-Bianchet 1991; Færevik, Andersen $246 \&$ Bøe 2005), and hoggets and wethers occupied lower positions in the social rank.

247 Generally, to avoid aggressive interactions, subordinate individuals use the resources after dominants and 248 are forced to feed on less preferred areas (Eccles \& Shackleton 1986; Prache, Gordon \& Rook 1998) while 249 high-ranked animals are generally unaffected by the proximity of subordinates (e.g. Bennett, Finch \& 250 Holmes 1985). This would mean that low-ranked individuals are more limited on their choices when high251 ranked individuals are present. Under this context, we would expect that, when these dominant individuals 
252 are removed from the flock, lower ranked individuals respond by showing a switch in their selection 253 patterns toward the most preferred areas. Although some studies focused on dominance levels of wethers 254 (Stolba et al. 1990; Keeling 2001) there is not a conclusive statement about their position in social ranks. 255 In this work, we did not observed any switch in the landscape use patterns of hoggets and ewes when 256 wethers were extracted from the flock. Moreover, when ewes were removed, only hoggets showed a 257 significant shift in their selectivity, strongly selecting most preferred areas and avoiding less preferred 258 areas. These results imply that reproductive females are upper positioned in the social rank, maybe due to 259 their higher energetic demands (Keeling 2001); wethers are more or less independent of this social rank 260 maybe associated to their relatively constant energetic demands generated by castration, and immature 261 individuals are at the lowest levels of this ranking.

262 Although there is evidence that age and body condition can be factors influencing animals' resource 263 selection and their social interactions (Festa-Bianchet 1991; Côté 2000; Veiberg et al. 2004; Vervaecke, 264 Roden \& de Vries 2005), we did not find evidence about the potential effects of these factors on the 265 landscape use of our sheep. This lack of evidence may be due to the fact that we did not have enough 266 variation in age or body condition score among sampled individuals, or because we would need a bigger 267 sample to assess those effects. Studies that found an effect of age and body condition on sheep social rank 268 were conducted on homogeneous flocks composed mostly of one sheep class and under pen or small 269 paddock conditions instead of rangelands. Nevertheless, the lack of effect of body condition could have 270 important implications on livestock productivity, because if sub-dominant individuals would be severely 271 food restricted under more heterogeneous flocks, we would expect a strong association between body 272 condition score and the use of less preferred areas and it was not the case in our results.

273 Unevenly distributed grazing, besides generating degradation of over-used areas, decreases the 274 productivity of under-grazed parts of the landscape mainly because of the accumulation of senescent material (Belsky 1986). Thus, if grazing distribution could be controlled, we could consider it as a

276 potential tool for natural grasslands conservation and recovery (see Weber et al. 1998; Adler, Raff \& 277 Lauenroth 2001). Even though the stocking rates were reduced when sheep shifted from a 3-class to a 2- 
278 class mixed flock, if our findings would have been related to the number of animals in a flock, we would

279 expect to find similar results if we would have removed ewes as we would have removed wethers, because

280 all sheep classes represented similar proportions of the flock. Nevertheless, we observed a marked switch

281 in grazing patterns, only after ewes were removed. For this reason, we propose that social

282 interactionamong flock members is the underlying mechanism that generates more evenly distributed

283 grazing patterns and the disruption of this social rank generates highly selective grazing patterns.

284 Considering that livestock resource selection patterns affect not only animals' nutritional levels (Stricklin,

285 Zhou \& Gonyou 1995) but also landscape dynamics (Adler, Raff \& Lauenroth 2001), our findings have

286 important management implications and provide information that could be used to decrease the negative

287 impacts of sheep grazing and maintain the long-term productivity of natural grasslands.

\section{Conclusions}

289 Several management tools have been proposed to homogenize livestock grazing patterns, such as water developments (Porath et al. 2002), fencing (Bailey, Walker \&Rittenhouse 1990), strategic supplement placement (Bailey et al 2001), herding (Rhodes \& Marlow 1997), and stocking density increasing (Savory 1983). However, most of these tools require relatively high investments (e.g., Bailey 2004) or resulted controversial (Briske et al. 2013; Cibils et al. 2014; Teague 2014). We are aware that the adoption of a novel management strategy strongly depends on ecological and economical constraints, and that social and cultural factors play a key role in this process (Borelli et al. 1997; Golluscio, Deregibus \& Paruelo 1998). In this work, we are suggesting to land managers and livestock producers an alternative for flock management that employs animals' behavioural interactions without the need for reducing livestock rates, modifying stocking densities or additional investments in labour and materials. Moreover, managing more heterogeneous mixed flocks can be combined with other strategies such as rotational grazing and the use of guardian dogs (to decrease the mortality levels that may be generated by sheep grazing on more risky habitats) to increase livestock productivity and landscape conservation.

\section{Acknowledgments}


303

304

305

306

307

308

309

310

311

312

313

314

315

316

317

318

319

320

321

322

323

324

325

326

327

328

329

330

331

332

333

334

335

336

337

338

339

340

341

342

343

344

345

We thank The Nature Conservancy and S. Gary for allowing us to conduct field work at Fortín Chacabuco

ranch; to F. Montenegro and N. Rodríguez for all the assistance and invaluable help and to G. Iglesias and

J. Beltrán for their support. Also, we thank M.L Villar for all her help and knowledge shared about sheep and livestock management; and A. Sáez and M.L. Villar for all their comments that improved the previous versions of this manuscript.

\section{References}

Adler, P., Raff, D. \& Lauenroth, W. (2001) The effect of grazing on the spatial heterogeneity of vegetation. Oecologia, 128, 465-479.

Arnold, G. \& Pahl, P. (1974) Some aspects of social behaviour in domestic sheep. Animal

Behaviour,22, 592-600.

Bailey, D. (2004) Management strategies for optimal grazing distribution and use of arid rangelands. Journal of Animal Science, 82, E147-E153.

Bailey, D., Kress, D., Anderson, D., Boss, D. \& Miller, E. (2001) Relationship between terrain use and performance of beef cows grazing foothill rangeland. Journal of Animal Science, 79, 1883-

1891.

Bailey, D., Walker, J. \& Rittenhouse, L. (1990) Sequential analysis of cattle location: day-to-day movement patterns. Applied Animal Behaviour Science, 25, 137-148.

Bailey, D.W., Dumont, B. \& WallisDeVries, M.F. (1998) Utilization of heterogeneous grasslands by domestic herbivores: theory to management. Annales de Zootechnie, pp. 321-333.

Bailey, D.W., Gross, J.E., Laca, E.A., Rittenhouse, L.R., Coughenour, M.B., Swift, D.M. \& Sims, P.L. (1996) Mechanisms that result in large herbivore grazing distribution patterns. Journal of range management, $\mathbf{4 9}, 386-400$.

Belsky, A. (1986) Does herbivory benefit plants? A review of the evidence. American Naturalist, 870-892.

Bennett, I., Finch, V.A. \& Holmes, C. (1985) Time spent in shade and its relationship with physiological factors of thermoregulation in three breeds of cattle. Applied Animal Behaviour Science, 13, 227-236.

Beyer, H.L., Haydon, D.T., Morales, J.M., Frair, J.L., Hebblewhite, M., Mitchell, M. \& Matthiopoulos, J. (2010) The interpretation of habitat preference metrics under use-availability designs. Philosophical Transactions of the Royal Society of London B: Biological Sciences,365, 2245-2254.

Bøe, K.E., Berg, S. \& Andersen, I.L. (2006) Resting behaviour and displacements in eweseffects of reduced lying space and pen shape. Applied Animal Behaviour Science, 98, 249-259. Bonvissuto, G. \& Somlo, R. (1995) Guías de condición para los principales tipos de campo de dos áreas ecológicas de Patagonia-Argentina. I. Precordillera. II. Sierras y Mesetas. En Seminariotaller: Producción, Nutrición y utilización de Pastizales. Grupo Regional Patagónico de Ecosistemas de Pastoreo. FAO-UNESCO/MAB-INTA (eds R. Somlo \& G. Becker), pp. 99. Trelew, Chubut.

Borelli, P. \& Oliva, G. (2001) Ganadería ovina sustentable en la Patagonia austral: tecnología de manejo extensivo. Ediciones Instituto Nacional de Tecnología Agropecuaria.

Borelli, P., Oliva, G., Williams, M., Gonzalez, L., Rial, P. \& Montes, L. (1997) Sistema regional de soporte de decisiones. Santa Cruz y Tierra del Fuego. Proyecto Prodeser. Buenos Aires: INTAGTZ,134. 
346

347

348

349

350

351

352

353

354

355

356

357

358

359

360

361

362

363

364

365

366

367

368

369

370

371

372

373

374

375

376

377

378

379

380

381

382

383

384

385

386

387

388

389

390

391

392

393

394

395

396
Borrelli, P., Oliva, G., Williams, M., Gonzalez, L., Rial, P. \& Montes, L. (1997) Sistema regional de soporte de decisiones. Santa Cruz y Tierra del Fuego. Proyecto Prodeser. Buenos Aires: INTAGTZ,134.

Boyd, C.S. \& Svejcar, T.J. (2009) Managing complex problems in rangeland ecosystems. Rangeland ecology \& management, 62, 491-499.

Briske, D., Bestelmeyer, B., Stringham, T. \& Shaver, P. (2008) Recommendations for development of resilience-based state-and-transition models. Rangeland ecology \& management, 61, 359-367.

Briske, D.D., Bestelmeyer, B.T., Brown, J.R., Fuhlendorf, S.D. \& Polley, H.W. (2013) The Savory Method can not green deserts or reverse climate change: a response to the Allan Savory TED video. Rangelands, 35, 72-74.

Cabrera, A.L. (1976) Regiones fitogeográficas argentinas, Second edn. Enciclopedia Argentina de Agricultura y Jardinería, Buenos Aires.

Cibils, A.F., Lira Fernández, R.J., Oliva, G.E. \& Escobar, J.M. (2014) Is Holistic Management

Really Saving Patagonian Rangelands From Degradation? A Response to Teague. Rangelands,36, 26-27.

Côté, S.D. (2000) Dominance hierarchies in female mountain goats: stability, aggressiveness and determinants of rank. Behaviour,137, 1541-1566.

Couzin, I.D., Krause, J., Franks, N.R. \& Levin, S.A. (2005) Effective leadership and decisionmaking in animal groups on the move. Nature,433, 513-516.

Childress, M. \& Lung, M. (2003) Predation risk, gender, and the group size effect: does elk vigilance depend upon the behavior of conspecifics? Animal Behaviour,66, 389-398.

Dudzinsky, M. \& Arnold, G. (1978) Ethology of free-ranging domestic animals. Elsevier

Scientific Publishers, New York.

Eccles, T. \& Shackleton, D. (1986) Correlates and consequences of social status in female bighorn sheep. Animal Behaviour,34, 1392-1401.

Erhard, H.W., Fàbrega, E., Stanworth, G. \& Elston, D.A. (2004) Assessing dominance in sheep in a competitive situation: level of motivation and test duration. Applied Animal Behaviour

Science, 85, 277-292.

Etzenhouser, M.J., Owens, M.K., Spalinger, D.E. \& Murden, S.B. (1998) Foraging behavior of browsing ruminants in a heterogeneous landscape. Landscape Ecology,13, 55-64.

Færevik, G., Andersen, I.L. \& Bøe, K.E. (2005) Preferences of sheep for different types of pen flooring. Applied Animal Behaviour Science,90, 265-276.

FAO(Food and Agriculture Organization of the United Nations) (2009) Review of evidence on drylands pastoral systems and climate change. Land and Water Discussion Paper 8, Land Tenure and Management Unit (NRLA) (eds Neely C, Bunning S \& W. A).Citeseer, Italy.

Favre, M., Martin J.G.A \& Festa-Bianchet, M. (2008). Determinants and life-history consequences of social dominance in bighorn ewes. Animal Behaviour, 76, 1373-1380.

Festa-Bianchet, M. (1991) The social system of bighorn sheep: grouping patterns, kinship and female dominance rank. Animal Behaviour,42, 71-82.

Fortin, D., Beyer, H.L., Boyce, M.S., Smith, D.W., Duchesne, T. \& Mao, J.S. (2005) Wolves influence elk movements: behavior shapes a trophic cascade in Yellowstone National Park. Ecology, 86, 1320-1330.

Fortin, D., Fortin, M.-E., Beyer, H.L., Duchesne, T., Courant, S. \& Dancose, K. (2009) Groupsize-mediated habitat selection and group fusion-fission dynamics of bison under predation risk. Ecology,90, 2480-2490.

Fortin, D., Fryxell, J.M., O'brodovich, L. \& Frandsen, D. (2003) Foraging ecology of bison at the landscape and plant community levels: the applicability of energy maximization principles.

Oecologia, 134, 219-227.

Fortin, D., Fryxell, J.M. \& Pilote, R. (2002) The temporal scale of foraging decisions in bison. Ecology, 83, 970-982. 
Frair, J.L., Merrill, E.H., Visscher, D.R., Fortin, D., Beyer, H.L. \& Morales, J.M. (2005) Scales of movement by elk (Cervus elaphus) in response to heterogeneity in forage resources and predation risk. Landscape Ecology, 20, 273-287.

Fryxell, J.M., Wilmshurst, J.F. \& Sinclair, A.R. (2004) Predictive models of movement by Serengeti grazers. Ecology, 85, 2429-2435.

Giraudo, C.G. (2010) El empleo de la condición corporal como indicador del estado nutricional de los ovinos. Presencia, 54, 32-35.

Golluscio, R., Deregibus, V. \& Paruelo, J.M. (1998) Sustainability and range management in the Patagonian steppes. Ecología Austral,8, 265-284.

Haydon, D.T., Morales, J.M., Yott, A., Jenkins, D.A., Rosatte, R. \& Fryxell, J.M. (2008) Socially informed random walks: incorporating group dynamics into models of population spread and growth. Proceedings of the Royal Society of London B: Biological Sciences, 275, 1101-1109. Irisarri, J.G.N., Oesterheld, M., Paruelo, J.M. \& Texeira, M.A. (2012) Patterns and controls of above-ground net primary production in meadows of Patagonia. A remote sensing approach. Journal of Vegetation Science,23, 114-126.

Jefferies, B. (1961) Body condition scoring and its use in management. Tasmanian journal of agriculture,32, 19-21.

Johnson, C.J., Nielsen, S.E., Merril, E.H., McDonald, T.L. \& Boyce, M.S. (2006) Resource Selection Functions Based on Use-Availability Data: Theoretical Motivation and Evaluation Methods. Journal of Wildlife Management, 70, 347-357.

Keeling, J. (2001) Social behavior in farm animals. CABI Publishing, Wallingford,UK.

Kie, J.G. (1999) Optimal foraging and risk of predation: effects on behavior and social structure in ungulates. Journal of Mammalogy,80, 1114-1129.

León, R.J., Bran, D., Collantes, M., Paruelo, J.M. \& Soriano, A. (1998) Grandes unidades de vegetación de la Patagonia extra andina. Ecología Austral,8, 125-144.

Lynch, J., Hinch, G., Bouissou, M., Elwin, R., Green, G. \& Davies, H. (1989) Social organization in young Merino and Merino $\times$ Border Leicester ewes. Applied Animal Behaviour Science, 22, 4963.

Lynch, J., Wood-Gush, D. \& Davies, H. (1985) Aggression and nearest neighbours in a flock of Scottish Blackface ewes. Biology of Behaviour (France), 10, 215-225. Lynch, J.J., Hinch, G. \& Adams, D. (1992) The behaviour of sheep: biological principles and implications for production. CAB international.

MA (Millennium Ecosystem Assessment) (2006) Millennium Ecosystem Assessment Synthesis Reports. http://maweb.org/en/Synthesis.aspx.Island Press: Washington, DC, USA. Manly, B., McDonald, L.L., Thomas, D.L., McDonald, T.L. \& Erickson, W.P. (2002) Resource Selection by Animals: Statistical Desing and Analysis for Field Studies, Second edn. Kluwer Academic Publishers.

Michelena, P., Henric, K., Angibault, J., Gautrais, J., Lapeyronie, P., Porter, R.H., Deneubourg, J. $\&$ Bon, R. (2005). An experimental study of social attraction and spacing betwwen sexes in sheep. Journal of Experimental Biology, 208, 4419-4426.

Morales, J.M., Moorcroft, P. R., Matthiopoulos, J., Frair, J.L., Kie, J.G., Powell, R.A., Merrill, E.H. \& Haydon, D.T. (2010). Building the bridge between animal movement and population dynamics. Philosophical Transactions of the Royal Society B, 365, 2289-2301. Morghan, K.J.R., Sheley, R.L. \& Svejcar, T.J. (2006) Successful adaptive management - the integration of research and management. Rangeland ecology \& management, 59, 216-219. Northrup, J.M., Hooten, M.B., Anderson Jr, C.R. \& Wittemyer, G. (2013) Practical guidance on characterizing availability in resource selection functions under a use-availability design. Ecology,94, 1456-1463.

Ormaechea, S. \& Peri, P. (2015) Landscape heterogeneity influences on sheep habits under extensive grazing management in Southern Patagonia. Livestock Research for Rural Development, 27.

Paramidani, M., Doffigny, C. \& Codesal, P. (2014) Estudio inicial de Pastizales Ea. "Fortín Chacabuco". Ovis XXI S.A. pp. 28. 
450

451

452

453

454

455

456

457

458

459

460

461

462

463

464

465

466

467

468

469

470

471

472

473

474

475

476

477

478

479

480

481

482

483

484

485

486

487

488

489

490

491

492

493

494

495

496

497

498

499

500

501
Petocz, R.G. (1973) The effect of snow cover on the social behavior of bighorn rams and mountain goats. Canadian Journal of Zoology,51, 987-993.

Pinchak, W.E., Smith, M.A., Hart, R.H. \& Waggoner Jr, J.W. (1991) Beef cattle distribution patterns on foothill range. Journal of range management,44, 267-275.

Plumb, G.E. \& Dodd, J.L. (1993) Foraging ecology of bison and cattle on a mixed prairie: implications for natural area management. Ecological Applications, 3, 631-643.

Porath, M., Momont, P., DelCurto, T., Rimbey, N., Tanaka, J.A. \& McInnis, M. (2002) Offstream water and trace mineral salt as management strategies for improved cattle distribution. Journal of Animal Science, 80, 346-356.

Prache, S., Gordon, I.J. \& Rook, A.J. (1998) Foraging behaviour and diet selection in domestic herbivores. Annales de Zootechnie, 47, 335-345.

Pringle, H.J. \& Landsberg, J. (2004) Predicting the distribution of livestock grazing pressure in rangelands. Austral Ecology, 29, 31-39.

R Core Team (2015) R: A language and environment for statistical computing. (ed. R Foundation for Statistical Computing https://www.R-project.org/). Vienna, Austria.

Rhodes, B. \& Marlow, C. (1997) Intensive range riding for improving livestock distribution. Abstracts, Society for Range Management Annual Meeting, pp. 21.

Risenhoover, K.L. \& Bailey, J.A. (1985) Foraging ecology of mountain sheep: implications for habitat management. The Journal of Wildlife Management, 49, 797-804.

Rubio, C.M.B., Cibils, A.F., Endecott, R.L., Petersen, M.K. \& Boykin, K.G. (2008) Pinon-juniper woodland use by cattle in relation to weather and animal reproductive state. Rangeland ecology \& management, 61, 394-404.

Savory, A. (1983) The Savory grazing method or holistic resource management. Rangelands, 155159.

Sayre, N.F., McAllister, R.R., Bestelmeyer, B.T., Moritz, M. \& Turner, M.D. (2013) Earth

Stewardship of rangelands: coping with ecological, economic, and political marginality. Frontiers in Ecology and the Environment, 11, 348-354.

Scott, C.B., Banner, R.E. \& Provenza, F.D. (1996) Observations of sheep foraging in familiar and unfamiliar environments: familiarity with the environment influences diet selection. Applied Animal Behaviour Science,49, 165-171.

Scott, C.B., Provenza, F.D. \& Banner, R.E. (1995) Dietary habits and social interactions affect choice of feeding location by sheep. Applied Animal Behaviour Science, 45, 225-237.

Seabloom, E.W. \& Reichman, O.J. (2001) Simulation Models of the Interactions between Herbivore Foraging Strategies, Social Behavior, and Plant Community Dynamics. The American Naturalist, 157, 76-96.

Senft, R., Coughenour, M., Bailey, D., Rittenhouse, L., Sala, O. \& Swift, D. (1987) Large herbivore foraging and ecological hierarchies. BioScience,37, 789-799.

Sibbald, A., Shellard, L. \& Smart, T. (2000) Effects of space allowance on the grazing behaviour and spacing of sheep. Applied Animal Behaviour Science, 70, 49-62.

Spiegelhalter, D., Thomas, A., Best, N. \& Gilks, W. (1996) BUGS 0.5: Bayesian inference using Gibbs sampling manual (version ii). MRC Biostatistics Unit, Institute of Public Health,

Cambridge, UK, 1-59.

Stenseth, N.C. (1983) Causes and consequences of dispersal in small mammals. The ecology of animal movement. (ed. J.R. Swingland, Greenwood, P.), pp. 63-101.Oxford University Press, Oxford.

Stolba, A., Hinch, G., Lynch, J., Adams, D., Munro, R. \& Davies, H. (1990) Social organization of Merino sheep of different ages, sex and family structure. Applied Animal Behaviour Science, 27, 337-349.

Stricklin, W., Zhou, J. \& Gonyou, H. (1995) Selfish animats and robot ethology: using artificial animals to investigate social and spatial behavior. Applied Animal Behaviour Science, 44, 187-203. Teague, R. (2014) Deficiencies in the Briske et al. rebuttal of the Savory method. Rangelands,36, 37-38. 
502

503

504

505

506

507

508

509

510

511
Thouless, C. (1990) Feeding competition between grazing red deer hinds. Animal Behaviour,40, 105-111.

Veiberg, V., Loe, L.E., Mysterud, A., Langvatn, R. \& Stenseth, N.C. (2004) Social rank, feeding and winter weight loss in red deer: any evidence of interference competition? Oecologia, 138, 135142.

Vervaecke, H., Roden, C. \& de Vries, H. (2005) Dominance, fatness and fitness in female American bison, Bison bison. Animal Behaviour,70, 763-770.

Weber, G.E., Jeltsch, F., Van Rooyen, N. \& Milton, S.J. (1998) Simulated long-term vegetation response to grazing heterogeneity in semi-arid rangelands. Journal of Applied Ecology,35, 687699. 


\section{Figure captions}

513 Figure 1: Resource Selection Functions mean estimates and 95\% Highest Posterior Density intervals for

514 the logistic model fitted to 3-class mixed flock for ewes (orange circles), hoggets (blue triangles) and

515 wethers (red squares) grazing at the three paddocks. Estimated values located above zero (dashed line)

516 indicate selection while values located below it indicate avoidance of the different vegetation units: low

517 production $(\mathrm{Lp})$, high-lands $(\mathrm{Hl})$, central wetlands $(\mathrm{Cw})$, peripheral wetlands $(\mathrm{Pw})$, grassland $(\mathrm{Gr})$,

518 shrubland-grassland (ShGr), native forest (Nf) and riparian forest (Rf). At Repunte-Bajo (a) all sheep

519 avoided low production areas, and the use of the rest of the vegetation units resulted similar, with the

520 exception of central and peripheral wetlands that were the most selected habitats for ewes. At Frison-

521 Guanaco (b) and Side (c) paddocks, all sheep avoided riparian forest and tended to use similarly all the

522 habitats, with the exception of ewes that tended to select more central and peripheral wetlands in

523 comparison to wethers and hoggets.

524 Figure 2: Resource Selection Function mean estimates and 95\% Highest Posterior Density intervals for the 525 logistic model fitted to data from hoggets (blue triangles) and wethers (red squares) grazing in 3-class (a)

526 and 2-class (b) mixed flocks after ewes were removed at Repunte-Bajo paddock. Estimated values located

527 above zero indicate selection and values located below it indicate avoidance of the different vegetation

528 units: low production (Lp), central wetlands $(\mathrm{Cw})$, peripheral wetlands $(\mathrm{Pw})$, grassland $(\mathrm{Gr})$, shrubland-

529 grassland (ShGr), native forest (Nf) and riparian forest (Rf).We can see that, when extracting ewes from

530 the flock (b), wethers and hoggets selected with more intensity central and peripheral wetlands; and

531 hoggets strongly avoided low production areas, native and riparian forest.

532 Figure 3: Resource Selection Function mean estimates and 95\% Highest Posterior Density intervals for the 533 logistic model fitted to data from hoggets (blue triangles) and ewes (orange circles) when grazing in a 3534 class mixed flock (a) and in a 2-class mixed flock after wethers were removed (b) at Side paddock. 535 Estimated values located above zero indicate selection and values located below it indicate avoidance of 536 the different vegetation units: central wetlands $(\mathrm{Cw})$, peripheral wetlands $(\mathrm{Pw})$, grassland $(\mathrm{Gr})$, shrubland- 
537 grassland (ShGr), native forest (Nf) and riparian forest (Rf). We can observe that when wethers were 538 extracted from the flock (b) the general pattern of resource reselection did not change considerably: Ewes 539 continued selecting with more intensity central and peripheral wetlands and that both sheep classes 540 avoided riparian forest, and used the rest of the landscape units similarly.

541 Figure 4: Diurnal movement patterns of sheep under 3-category and 2-category mixed flocks at Repunte542 Bajo paddock. When sheep were grazing in a 3-category mixed flock (a), we can see that, although the 543 ewe (orange path) showed a directed path towards the most preferred area (1), the other two classes 544 showed a more distributed space use (2). After ewes were removed from the landscape (b), wethers (red 545 path) and hoggets (blue path), concentrated their movements on the central and peripheral wetlands (3), 546 which are the most preferred areas. To see more images of sheep movement patterns see Supplemental 547 Information S5. 


\section{Figure $\mathbf{1}$ (on next page)}

Figure 1

Resource Selection Functions mean estimates and 95\% Highest Posterior Density intervals for the logistic model fitted to 3-class mixed flock for ewes (orange circles), hoggets (blue triangles) and wethers (red squares) grazing at the three paddocks. Estimated values located above zero (dashed line) indicate selection while values located below it indicate avoidance of the different vegetation units: low production (Lp), high-lands (HI), central wetlands (Cw), peripheral wetlands (Pw), grassland (Gr), shrubland-grassland (ShGr), native forest (Nf) and riparian forest (Rf). At Repunte-Bajo (a) all sheep avoided low production areas, and the use of the rest of the vegetation units resulted similar, with the exception of central and peripheral wetlands that were the most selected habitats for ewes. At Frison-Guanaco (b) and Side (c) paddocks, all sheep avoided riparian forest and tended to use similarly all the habitats, with the exception of ewes that tended to select more central and peripheral wetlands in comparison to wethers and hoggets. 


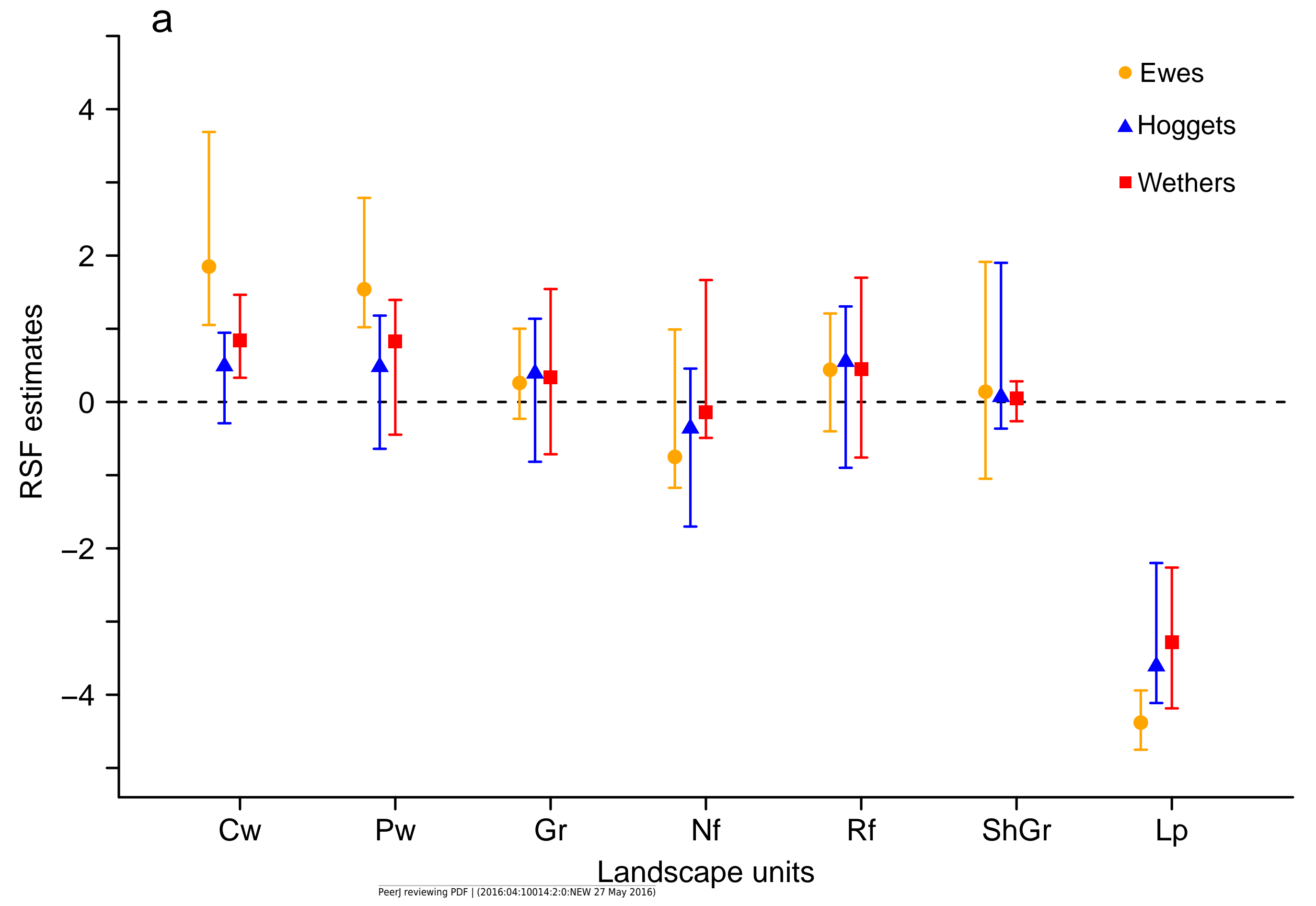




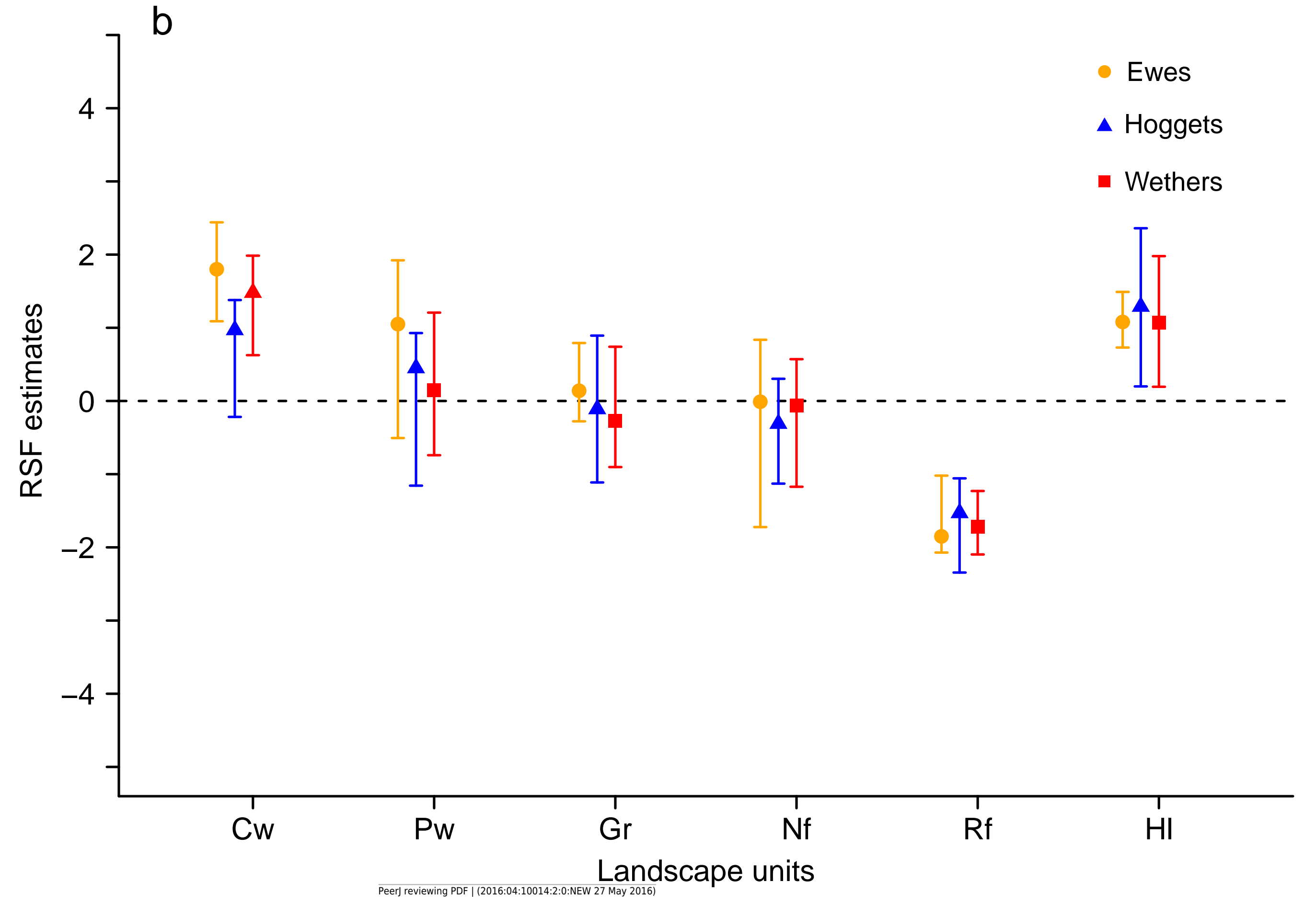




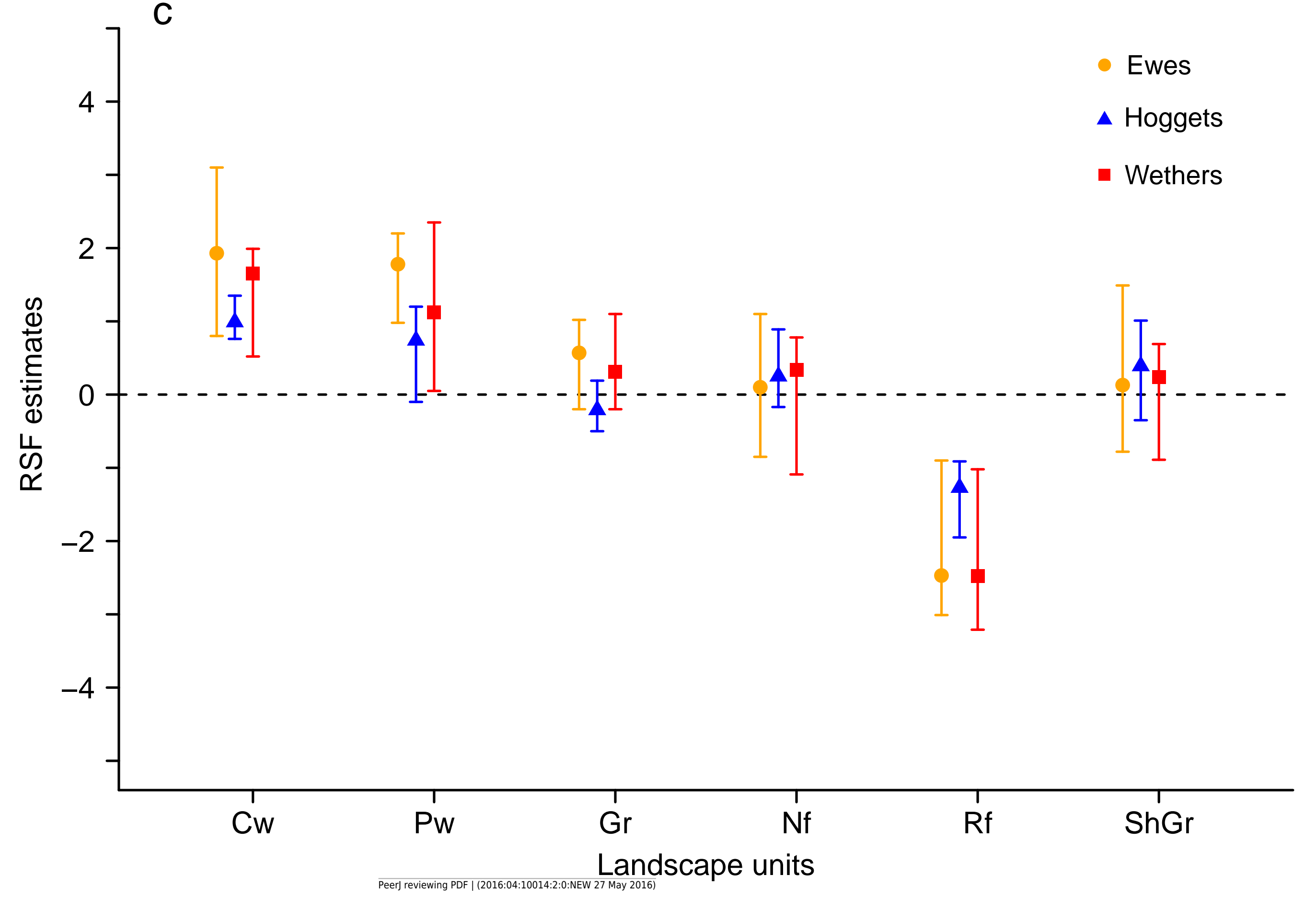




\section{Figure 2 (on next page)}

Figure 2

Resource Selection Function mean estimates and 95\% Highest Posterior Density intervals for the logistic model fitted to data from hoggets (blue triangles) and wethers (red squares) grazing in 3-class (a) and 2-class (b) mixed flocks after ewes were removed at Repunte-Bajo paddock. Estimated values located above zero indicate selection and values located below it indicate avoidance of the different vegetation units: low production (LP), central wetlands $(\mathrm{CW})$, peripheral wetlands (Pw), grassland (Gr), shrubland-grassland (ShGr), native forest (Nf) and riparian forest (Rf).We can see that, when extracting ewes from the flock (b), wethers and hoggets selected with more intensity central and peripheral wetlands; and hoggets strongly avoided low production areas, native and riparian forest. 


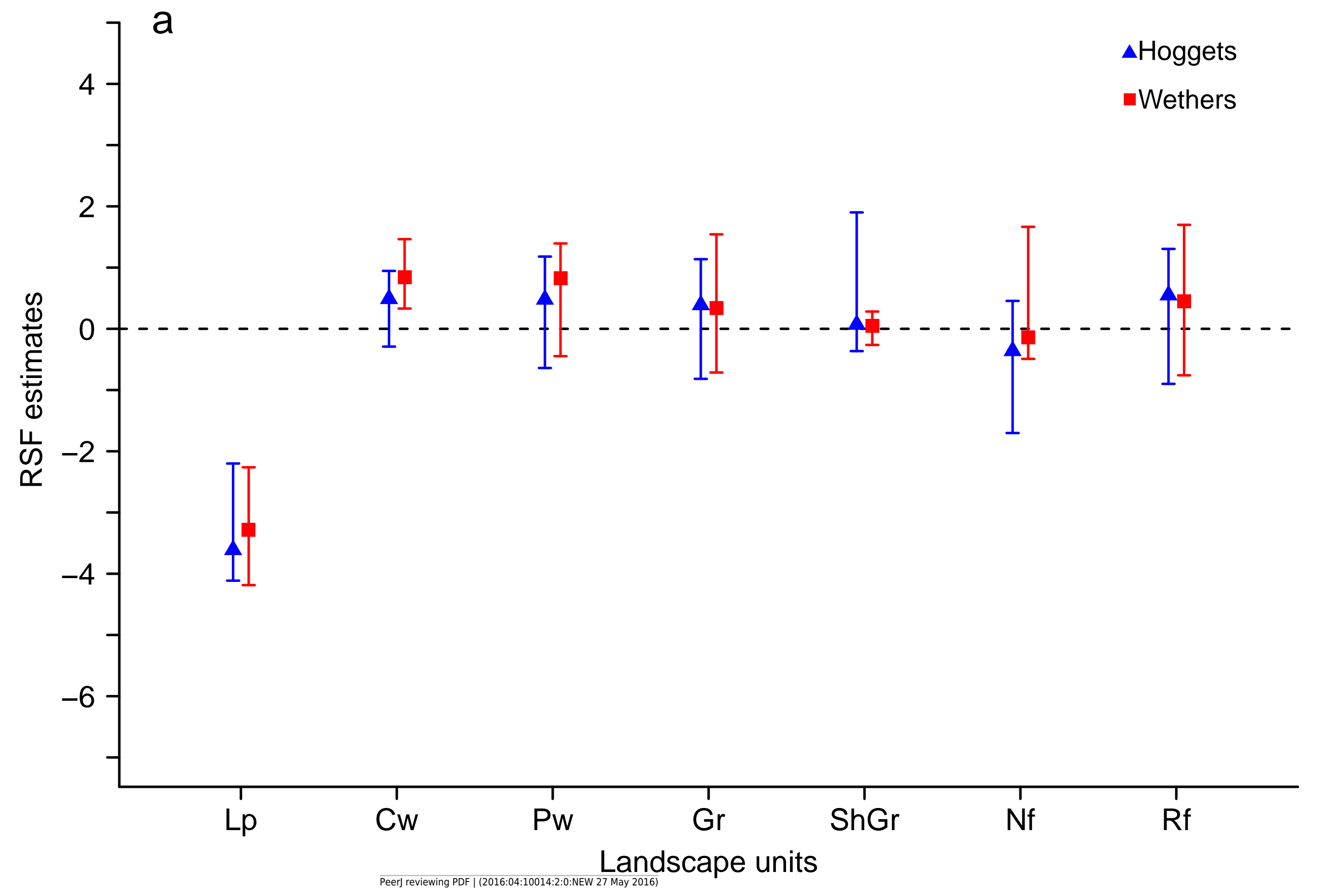




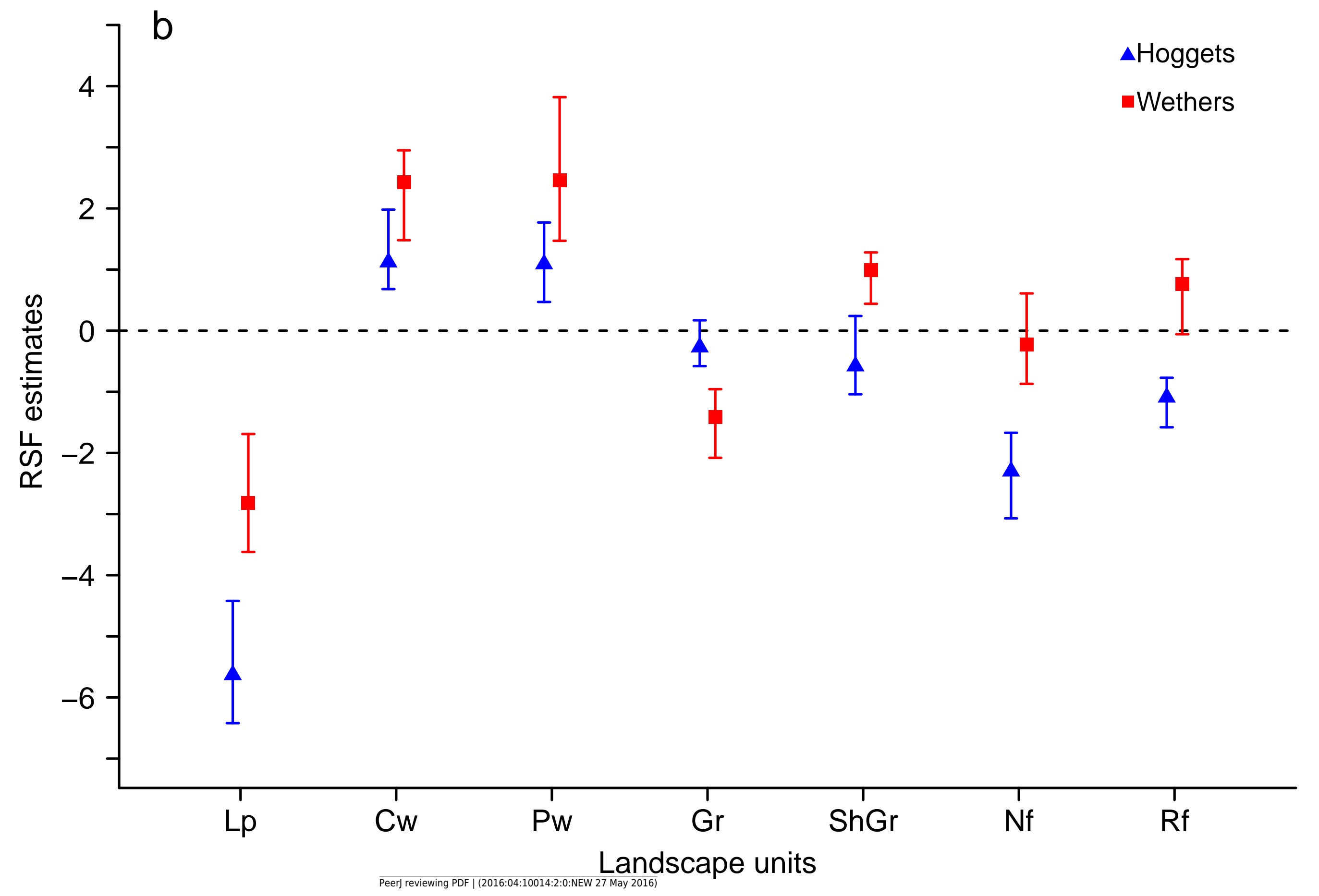




\section{Figure 3 (on next page)}

Figure 3

Resource Selection Function mean estimates and 95\% Highest Posterior Density intervals for the logistic model fitted to data from hoggets (blue triangles) and ewes (orange circles) when grazing in a 3-class mixed flock (a) and in a 2-class mixed flock after wethers were removed (b) at Side paddock. Estimated values located above zero indicate selection and values located below it indicate avoidance of the different vegetation units: central wetlands ( $\mathrm{Cw}$ ), peripheral wetlands (Pw), grassland (Gr), shrubland-grassland (ShGr), native forest (Nf) and riparian forest (Rf). We can observe that when wethers were extracted from the flock (b) the general pattern of resource reselection did not change considerably: Ewes continued selecting with more intensity central and peripheral wetlands and that both sheep classes avoided riparian forest, and used the rest of the landscape units similarly. 


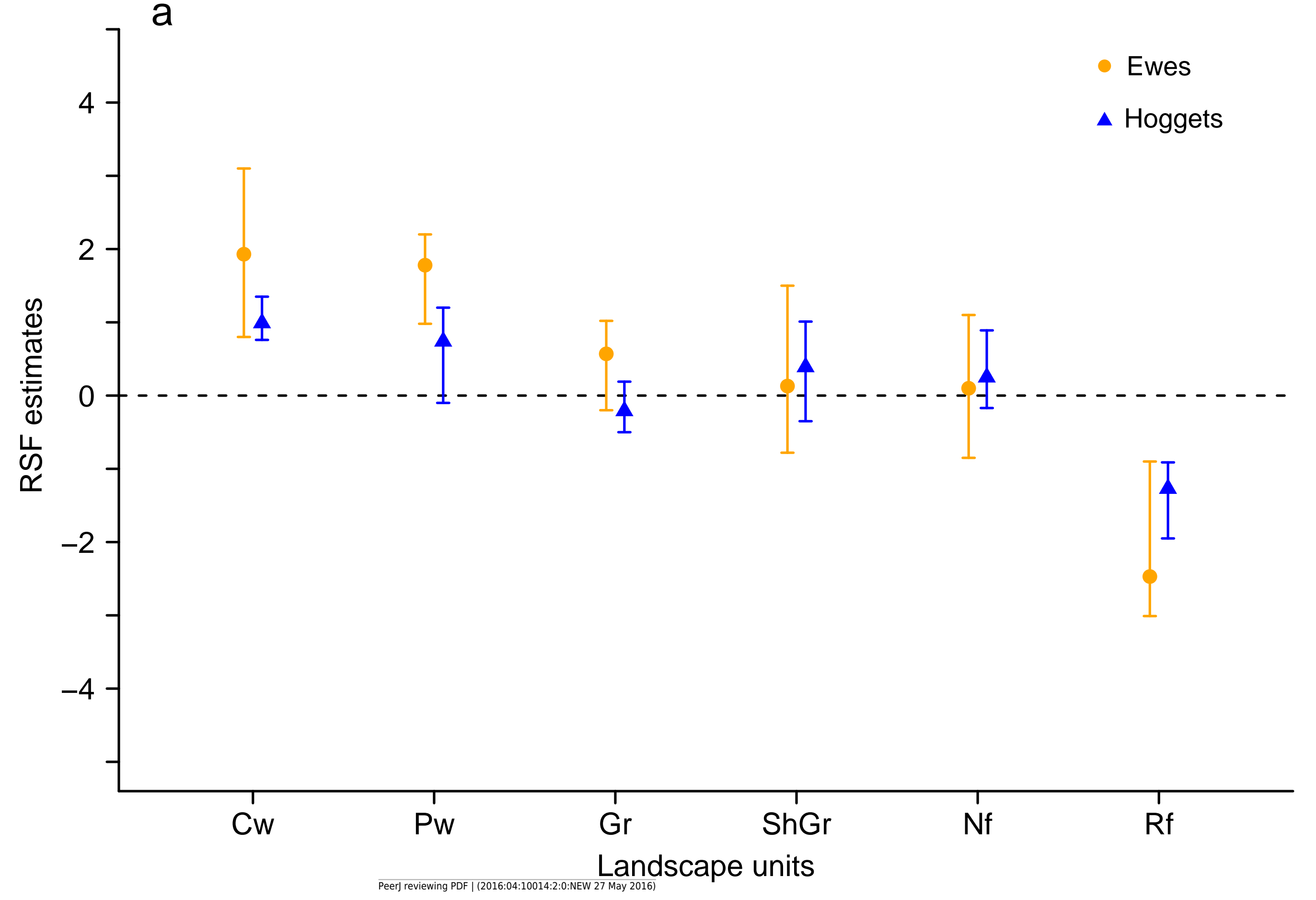




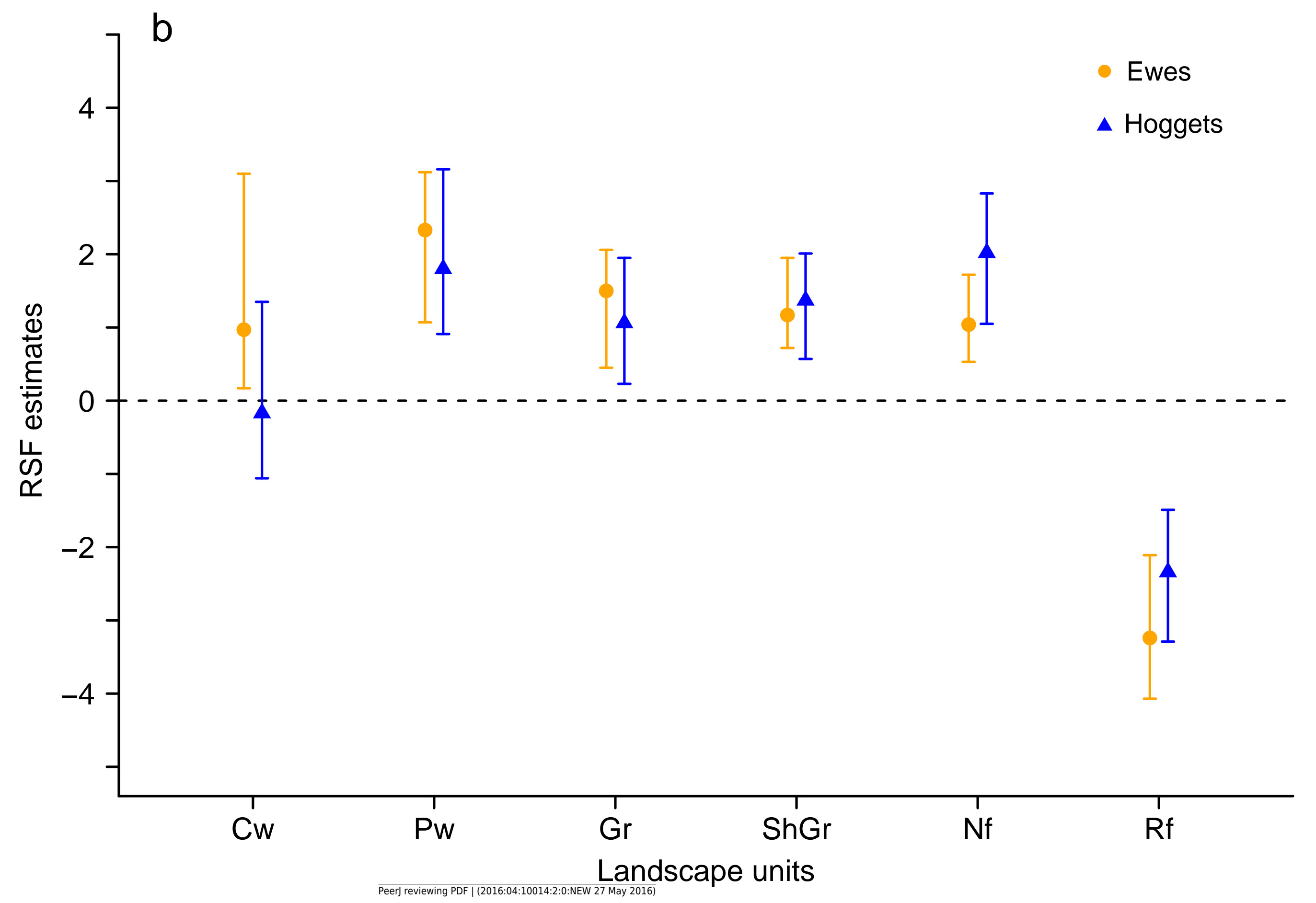




\section{4}

Figure 4

Diurnal movement patterns of sheep under 3-category and 2-category mixed flocks at Repunte-Bajo paddock. When sheep were grazing in a 3-category mixed flock (a), we can see that, although the ewe (orange path) showed a directed path towards the most preferred area (1), the other two classes showed a more distributed space use (2). After ewes were removed from the landscape (b), wethers (red path) and hoggets (blue path), concentrated their movements on the central and peripheral wetlands (3), which are the most preferred areas. To see more images of sheep movement patterns see Supplemental Information S5. 


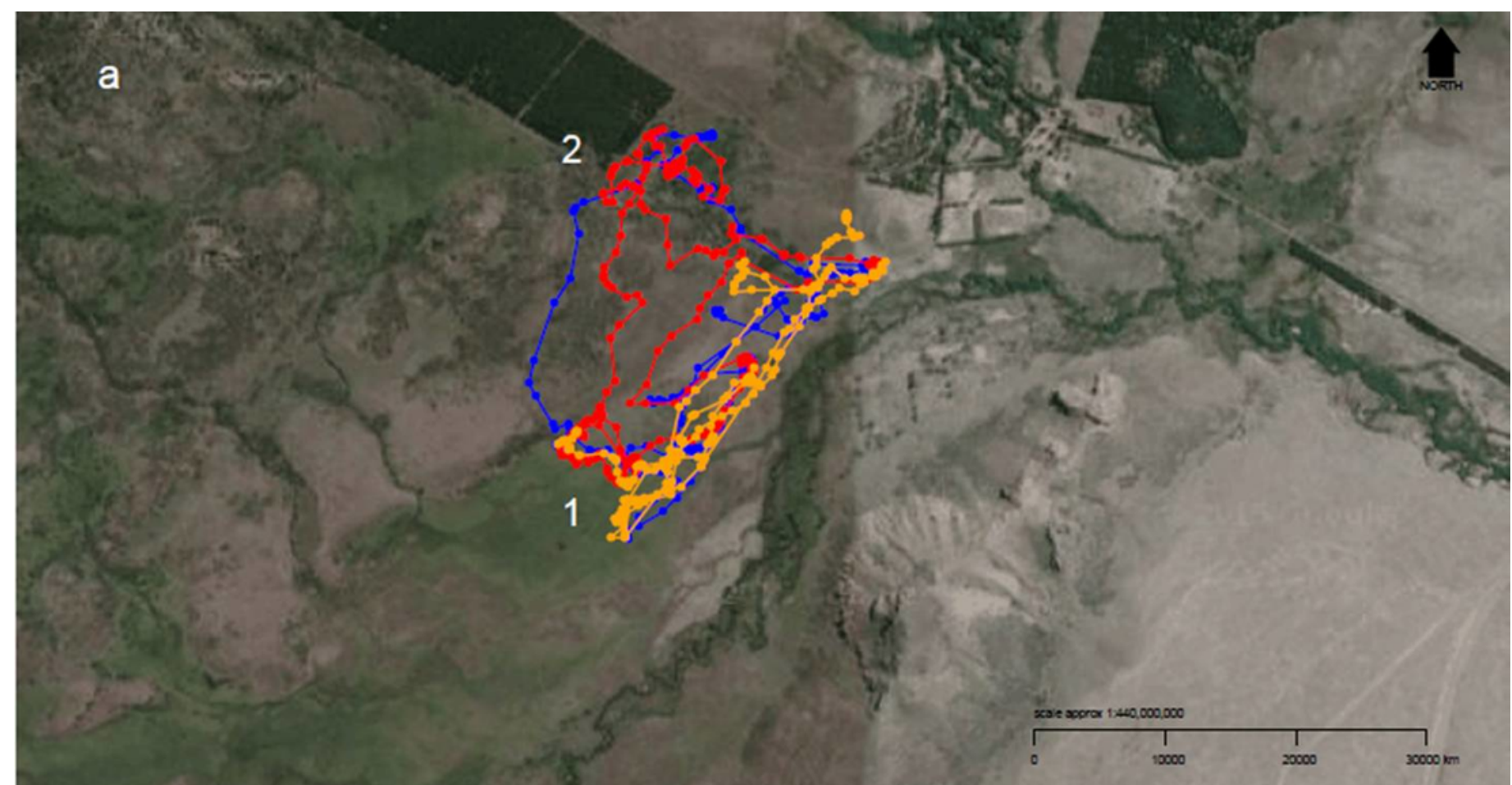

Google

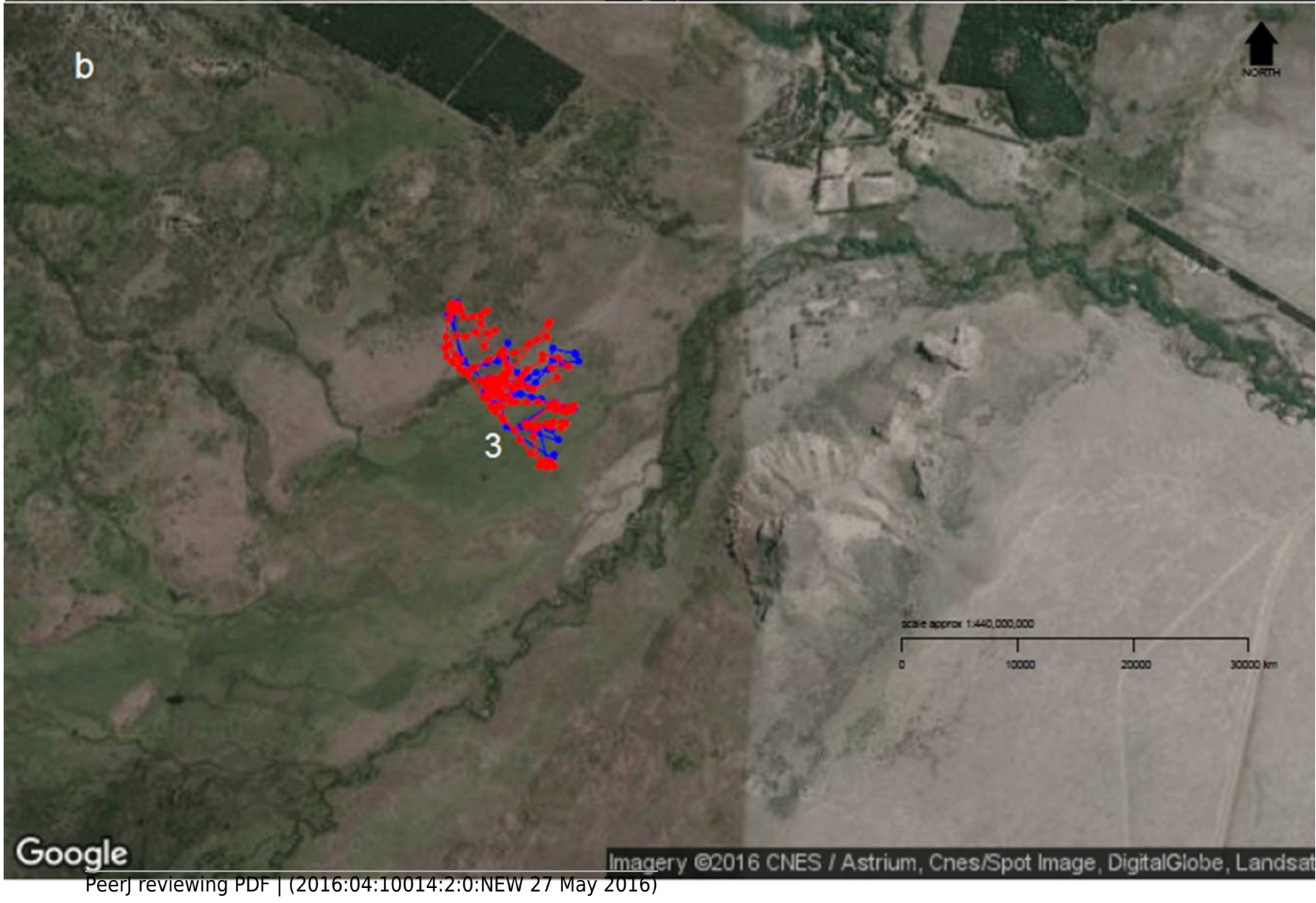




\section{Table $\mathbf{1}$ (on next page)}

Table 1

Description of datasets used for each analysis, including the paddock considered, the type of flock, the number of individuals included of each sheep class, and the period and its length in days. The data correspond to the same animals, and the difference in the total number of individuals occurs when some devices did not work because they had run out of batteries. 
1 Table 1: Description of datasets used for each analysis, including the paddock considered, the type of

2 flock, the number of individuals included of each sheep class, and the period and its length in days.

\begin{tabular}{|c|c|c|c|c|}
\hline Database & Paddock & Flock type & $\begin{array}{l}\text { Number of } \\
\text { individuals }\end{array}$ & Period \\
\hline $\mathrm{RB}_{3 \mathrm{C}-\text {-mixed }}$ & $\begin{array}{l}\text { Repunte } \\
\text { Bajo }\end{array}$ & $\begin{array}{c}3 \text { classes: } \\
\text { ewes, hoggets, and } \\
\text { wethers }\end{array}$ & $\begin{array}{l}19 \text { in total: } \\
6 \text { ewes, } 7 \text { hoggets } \\
\text { and } 6 \text { wethers }\end{array}$ & $\begin{array}{c}\text { September-November } 2014 \\
\text { and April-May } 2015 \\
\text { (Length: } 77 \text { days) }\end{array}$ \\
\hline $\mathrm{FG}_{3 \mathrm{C}-\text {-mixed }}$ & $\begin{array}{l}\text { Frison- } \\
\text { Guanaco }\end{array}$ & $\begin{array}{c}3 \text { classes: } \\
\text { ewes, hoggets and } \\
\text { wethers }\end{array}$ & $\begin{array}{l}18 \text { in total: } \\
6 \text { ewes, } 7 \text { hoggets } \\
\text { and } 5 \text { wethers }\end{array}$ & $\begin{array}{l}\text { February-August } 2015 \\
\text { (Length: } 164 \text { days) }\end{array}$ \\
\hline $\mathrm{S}_{3 \mathrm{C}-\text { mixed }}$ & Side & $\begin{array}{c}3 \text { classes: } \\
\text { ewes, hoggets and } \\
\text { wethers }\end{array}$ & $\begin{array}{l}15 \text { in total: } \\
6 \text { ewes, } 5 \text { hoggets } \\
\text { and } 4 \text { wethers }\end{array}$ & $\begin{array}{l}\text { September } 2015 \\
\text { (Length: } 30 \text { days) }\end{array}$ \\
\hline $\mathrm{RB}_{2 \mathrm{C} \text {-mixed }}$ & $\begin{array}{l}\text { Repunte } \\
\text { Bajo }\end{array}$ & $\begin{array}{c}2 \text { classes: } \\
\text { wethers and hoggets }\end{array}$ & $\begin{array}{c}6 \text { in total: } \\
2 \text { wethers and } 4 \\
\text { hoggets }\end{array}$ & $\begin{array}{l}\text { November-January } 2014 \\
\text { (Length: } 78 \text { days) }\end{array}$ \\
\hline $\mathrm{S}_{2 \mathrm{C}-\mathrm{mixed}}$ & Side & $\begin{array}{l}2 \text { classes: } \\
\text { ewes and hoggets }\end{array}$ & $\begin{array}{l}8 \text { in total: } \\
5 \text { ewes and } 3 \\
\text { hoggets }\end{array}$ & $\begin{array}{c}\text { January and September } 2015 \\
\text { (Length: } 39 \text { days) }\end{array}$ \\
\hline
\end{tabular}

